\title{
Cyclooxygenase-2-Dependent and Thromboxane-Dependent Vascular and Bronchial Responses are Regulated via p38 Mitogen-Activated Protein Kinase in Control and Endotoxin-Primed Rat Lungs
}

\author{
Monika Ermert, Daniel Kuttner, Nils Eisenhardt, Christian Dierkes, Werner Seeger, \\ and Leander Ermert
}

Departments of Pathology (ME, CD, LE) and Internal Medicine (DK, NE, WS), Justus-Liebig-University Giessen, Giessen, Germany

\begin{abstract}
SUMMARY: Mitogen-activated protein kinases (MAPKs) are part of an intracellular signaling machinery consisting of three known distinct pathways, each leading to activation of a different protein kinase: p38, ERK (extracellular signal-regulated kinase), or JNK (c-Jun N-terminal kinase). We investigated the role of the p38 MAPK pathway in the phenomenon of lung endotoxin "priming": incubation of perfused rat lungs with lipopolysaccharide (LPS) for 2 hours results in drastically enhanced cyclooxygenase-2-dependent and thromboxane synthase-dependent vasoconstriction and bronchoconstriction, including edema formation in response to a second inflammatory stimulus, such as arachidonic acid application. Two unrelated selective inhibitors of p38 (SB203580 and SC-68376) dose dependently suppressed the arachidonic acid-induced pulmonary artery pressor response, edema formation, and bronchoconstrictor response in both control lungs and lungs that underwent preceding endotoxin priming. In parallel, thromboxane, but not prostacyclin, released into the lung perfusate was dose dependently inhibited. Using immunohistochemical techniques in combination with quantitative microdensitometry, p38 was detected in nearly all cell types in control lungs, whereas the activated form p-p38 was only expressed in certain cell types, eg, bronchial epithelial cells, endothelial cells, alveolar macrophages, and vascular smooth muscle cells (SMC) of small vessels. In response to endotoxin, p-p38 expression was additionally observed in septal cells, bronchial SMC, and vascular SMC of larger pulmonary vessels and was increased in most other cell types including small-vessel SMC. We conclude that both immunolocalization of p38 activity and pharmacologic interventions support a strong role of the p38 MAPK pathway in establishing an active cyclooxygenase-2/thromboxane synthase axis in vascular and bronchial SMC, with up-regulation of this signaling cascade occurring in LPS priming and being responsible for enhanced pulmonary artery pressor response, edema formation, and bronchoconstriction. Moreover, LPS induces or increases phosphorylation of p38 in other lung cell types. The physiologic consequences of these events remain to be established. (Lab Invest 2003, 83:333-347).
\end{abstract}

$B_{\text {tata }}$ acterial endotoxins (lipopolysaccharide [LPS]) initiate a complex response pattern in the lung, which may well contribute to the development of acute respiratory failure during sepsis or severe pneumonia (Brigham and Meyrick, 1986; Ulevitch, 1991). After exposure of the lung to microbial or inflammatory agents, various cell types are activated; in many cells, phosphorylation cascades of kinases are part of the intracellular signaling that underlie specific functional responses (Cuenda et al, 1997; McLeish et al, 1998;

DOI: 10.1097/01.LAB.0000059924.47118.88

Received June 12, 2002.

This publication includes parts of the thesis of D. Kuttner in partial fulfillment for the degree of M.D. This work was supported by the Deutsche Forschungsgemeinschaft (SFB 547 "Kardiopulmonales Gefäßsystem").

Address reprint requests to: Dr. L. Ermert, Institut fuer Anatomie und Zellbiologie, Aulweg 123, 35385 Giessen, Germany. E-mail: leander.ermert@anatomie.med.uni-giessen.de
Raingeaud et al, 1995). A family of mitogen-activated protein kinases (MAPK) has specifically been implicated in signaling events that are potentially important in the inflammatory response. Three distinct signal transduction pathways (ERK [extracellular signalregulated kinase], p38, and JNK [c-Jun N-terminal kinase]) have been described, which may differentially mediate inflammatory responses to different stimuli (Feng et al, 1999; Newton et al, 2000; Paul et al, 1997).

Activation of the p38 MAPK is the final step in a cascade of intracellular signal transduction enzymes possibly involved in the regulation and generation of numerous proinflammatory mediators such as TNF, IL-1, and IL-6 (Laporte et al, 2000; Ono and Han, 2000) and inducible enzymes such as cyclooxygenase-2 (Cox-2) or inducible nitric oxide synthase (Chen et al, 1999; Ermert et al, 2002; Guan et al, 1998; Newton et al, 2000), which have been implicated in the pathogenesis of inflammatory lung diseases (eg, acute 
respiratory distress syndrome). Three p38 homologs, $\mathrm{p} 38 \beta, \mathrm{p} 38 \gamma$ (or ERK6, SAPK3 [stress activated protein kinase 3]), and p38 $\delta$ (or SAPK4), have been cloned and described in mammals (Ono and Han, 2000). p38 and its closest homolog $\mathrm{p} 38 \beta$ are thought to be ubiquitously expressed, whereas expression of the homologs $\mathrm{p} 38 \gamma$ and $\mathrm{p} 38 \delta$ seems to be more restricted (Lee et al, 2000).

Endotoxin (LPS) priming in isolated rat lungs has been previously shown to induce Cox-2/thromboxanedependent enhanced vascular and bronchial pressor responses, detectable upon subsequent stimulation with different bacterial exotoxins or arachidonic acid. Such responses are reminiscent of vascular abnormalities and changes in bronchomotor tone occurring during septic lung disease (Ermert et al, 2000a, 2000b, 2000c). A cell type-specific regulation pattern of Cox-2 and thromboxane synthase was shown to underlie the specific LPS priming-related responses (Ermert et al, 2000b, 2000c). For example, upregulation of Cox-2 and thromboxane synthase in vascular smooth muscle cells (VSMC) of pulmonary resistance vessels was in accordance with the elevated vasopressor response observed in lungs with LPS priming (Ermert et al, 2000c). The Cox-2 regulation in lung tissue was shown to be CD14 dependent (Ermert et al, 2000b), thus requiring soluble plasma factors such as sCD14 or lipopolysaccharide-binding protein (LBP) for the initiation of the LPS-mediated priming response.

Studies performed in macrophage cell lines stimulated with LPS suggest that the activation of p38 MAPK may be necessary for LPS-induced signaling, resulting in enhanced Cox-2 expression (Chen et al, 1999; Hwang et al, 1997). In accordance with the endotoxin-elicited Cox-2 regulation in lungs (Ermert et al, 2000b), p38 activation in response to LPS challenge is expected to be influenced by plasma factors.

LPS effects are mediated via cellular membrane receptors and via soluble receptors and plasma proteins, such as LBP (Pugin et al, 1993; Wright et al, 1990). Among the LPS receptors characterized earlier (Ingalls and Golenbock, 1995; Pugin et al, 1993; Wright et al, 1990), none were capable of mediating an LPS signal across the cellular membrane. However, the recently identified Toll-like receptors (TLR) fulfill such a function, thus representing a specific receptor system for pathogen recognition (O'Neill, 2001). Although TLR-2 is assumed to bind predominantly Gram-positive bacterial wall components such as lipoteichoic acid or peptidoglycan (Schwandner et al, 1999; Yoshimura et al, 1999), TLR-4 was identified as the primary LPS receptor responsible for mediating the LPS-induced intracellular signal transduction (Hoshino et al, 1999; Qureshi et al, 1999). CD14 is assumed to be an important coreceptor of the LPSreceptor complex but lacks an intracellular domain (Haziot et al, 1996). Activation of MAPK by LPS in macrophages (Rao, 2001) and transfected embryonic kidney cells (Yang et al, 2000) has recently been shown to involve both CD14 and TLR.

The current study focused on the involvement of p38 MAPK in the LPS-induced signaling events underlying the lung priming to subsequent inflammatory stimuli. Cell-specific regulation and activation of p38 MAPK were investigated by an in situ microdensitometric method (Ermert et al, 2001). Highly specific Abs for the detection of phosphorylated (activated) protein kinases allowed us to evaluate the cell type-specific activation status of MAP kinases within the intact lung. Selective inhibitors of p38 MAPK SB203580 and SC68376 were used as pharmacologic tools (Cuenda et al, 1995; Kumar et al, 1999). In essence, we provide strong evidence that activation of the p38 MAP kinase is centrally involved in the LPS priming response in different lung cells, resulting in enhanced Cox-2dependent vascular and bronchial response to subsequent inflammatory stimuli. These findings may be of interest for developing new therapeutic strategies for the treatment of inflammatory lung disease.

\section{Results}

\section{Isolated Buffer-Perfused Lung Experiments}

In control lungs, no weight gain $(\Delta W)$ or change in pulmonary artery pressure (PAP) or ventilation pressure (VP) was registered during the entire observation period of 2 hours. In the absence of preceding LPS administration, a rapid increase in PAP by $\sim 3$ to 4 $\mathrm{mmHg}$ was provoked within 5 minutes by application of free arachidonic acid (AA) (10 $\mu \mathrm{mol} / \mathrm{L})$ (Fig. 1).
A

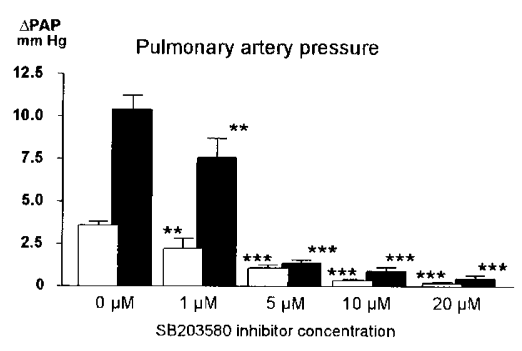

B

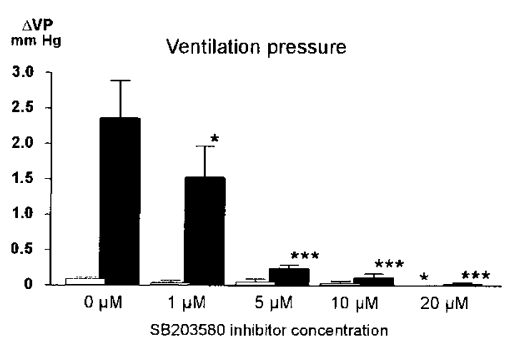

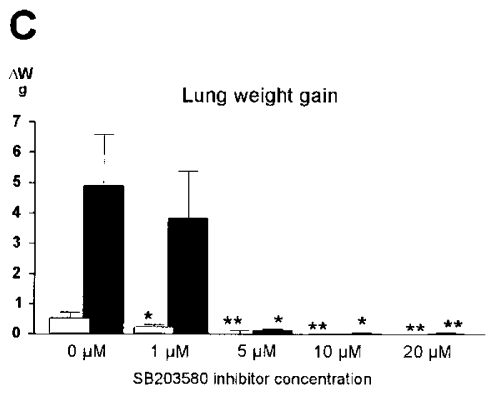

Figure 1.

Impact of p-38 mitogen-activated protein kinase (MAPK) inhibition on cyclooxygenase-2 (Cox-2)-dependent vasotone and bronchotone responses and weight increase in nonstimulated and lipopolysaccharide (LPS)-primed lungs. Mean \pm SEM of five independent experiments each are given. ${ }^{*} p<0.05,{ }^{* \star} p<0.01,{ }^{* *} p$ $<0.001$ for comparison with lungs that received vehicle administration. 
Concomitantly, $\Delta \mathrm{W}(\sim 0.5 \mathrm{gm})$ was noted (Fig. 1), whereas VP remained unchanged in response to $A A$ administration.

In lungs perfused with $10,000 \mathrm{ng} / \mathrm{ml}$ LPS, the PAP, $V P$, and $\Delta W$ were within normal ranges during a period of 2 hours. Responsiveness to $A A$ challenge was, however, markedly enhanced (Fig. 1): the PAP increase was in the range of 10 to $11 \mathrm{mmHg}$, accompanied by an exaggerated increase in VP $(\sim 5 \mathrm{mmHg})$ and weight (2-3 gm), in correspondence with previous studies from this laboratory (Ermert et al, 2000c).

Application of the p38 inhibitor SB203580 dose dependently suppressed $\triangle \mathrm{PAP}$ to near baseline values both in control and LPS-treated lungs. In addition, $\Delta \mathrm{VP}$ and $\Delta \mathrm{W}$ were both reduced by p38 inhibition (Fig. 1). In parallel, thromboxane $B_{2}\left(T x B_{2}\right)$ perfusate levels were significantly decreased after $A A$ challenge in the presence of p38 inhibitors (Fig. 2) in both control and LPS-stimulated lungs. In contrast, 6-keto prostaglandin $\mathrm{F}_{1 \alpha}$ (6-keto $\mathrm{PGF}_{1 \alpha}$ ) levels in the buffer perfusate were not influenced by p38 inhibition either under control or LPS priming conditions (Fig. 2). Application of a second independent p38 inhibitor, SC-68376, produced comparable results (data not shown).

\section{Immunohistochemistry}

Control Lungs. In both rapidly excised and bufferperfused or buffer/plasma-perfused control lungs, constitutive expression of p38 MAPK was equally detected in nearly all lung cell types (Tables 1 and 2). Only VSMC of large, mainly elastic arteries at the lung hilum did not express p38. Phosphorylated p38 was found, however, only in a few lung cells under physiologic conditions (Tables 3 and 4, Fig. 3). Concerning the airways, bronchial epithelial cells showed p38 activity, whereas p38 activity was not found in bronchial smooth muscle cells (BSMC) and bronchusassociated lymphoid tissue (BALT), which both ex-

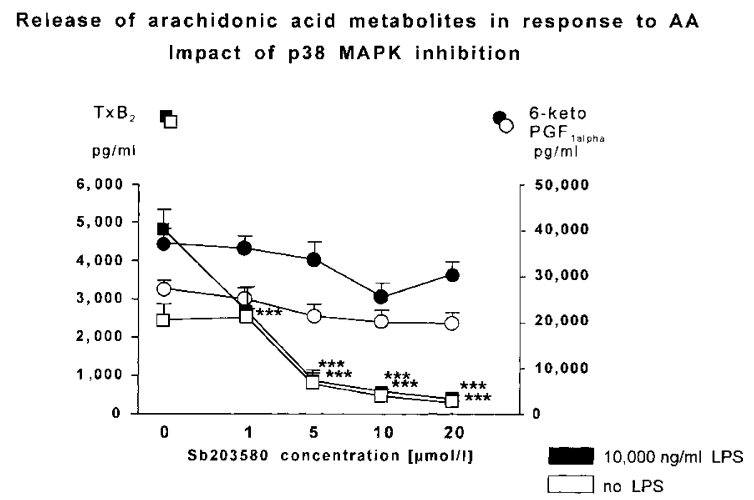

Figure 2.

Arachidonic acid (AA)-induced prostanoid release: impact of p38 inhibition. Lungs were buffer-perfused in the absence (open bars) or presence (closed bars) of $10,000 \mathrm{ng} / \mathrm{ml} \mathrm{LPS}$, and AA challenge $(10 \mu \mathrm{mol} / \mathrm{L})$ was undertaken after 2 hours. The selective p38 inhibitor SB203580 (vehicle or 1-20 $\mu \mathrm{mol} / \mathrm{L}$ ) was admixed to the buffer fluid 60 minutes after LPS administration. Means \pm SEM of $\mathrm{TXB}_{2}$ and 6-keto $\mathrm{PGF}_{1 \alpha}$, detected in the perfusate 5 minutes after AA challenge, are given ( $n=$ five independent experiments each). ${ }^{* *} p<0.001$ for comparison with lungs that received vehicle administration. pressed p38 (Tables 3 and 4, Fig. 3, A and B). Within the pulmonary vasculature, the activated form of p38 (p-p38) was noted in endothelial cells and in VSMC of only the small partially muscular vessels, whereas p38 in the muscle layer of larger vessels was not active (Tables 3 and 4, Fig. 3, C to F). Within the lung tissue, alveolar macrophages and leukocytes were positive for both p38 and the activated enzyme p-p38, whereas septal cells, which predominantly represent type II pneumocytes, expressed p38 but not in its activated form.

\section{p38/p-p38 Expression in Response to LPS}

Different cellular patterns of p38 expression and activation were noted in lung tissue subsequent to LPS application.

(A) p38 expression (Tables 1 and 2, Fig. 4) showed a short-term increase of staining intensity at 1 hour after LPS application, especially in VSMC of intrapulmonary vessels (Fig. 4, A and B), endothelial cells (Fig. 4, C and D), and alveolar macrophages (Fig. 4, E and $F)$. This was followed by a significant decrease in p38 staining intensity by 2 hours after LPS application. In most other pulmonary cells types, p38 expression was rapidly down-regulated in response to LPS stimulation (Tables 1 and 2).

(B) In response to LPS stimulation, activity of p38 (p-p38) was newly induced in VSMC of fully muscular vessels (Tables 3 and 4, Fig. 5, A and B). In addition, immunoreactivity for phosphorylated p38 was newly detected in BSMC (Fig. 5, C and D) and in septal cells, which were thought to be primarily type II pneumocytes (Fig. 5, E and F).

(C) All other pulmonary cells, which already expressed p-p38 under baseline conditions (Tables 3 and 4), showed time-dependent enhanced signal intensity at 1 hour after LPS application (Fig. 6). Among other cell types (Tables 3 and 4), endothelial cells (Fig. 5B), bronchial epithelial cells (Fig. 5D), and alveolar macrophages (Fig. 5F) displayed increased p-p38 signal intensity in response to LPS. Although p-p38 fell below baseline levels in all other pulmonary cell types (Fig. 6, A to C) 2 hours after LPS stimulation, p-p38 signal intensity still increased in leukocytes located in a perivascular or peribronchial position (Fig. 6D).

(D) No change in immunoreactivity or signal intensity of p38 or p-p38 in comparison to control lungs was detected in nerve fibers, cells of the BALT, and cardiac myocytes of the large hilum veins (Tables 1 to 4 ).

\section{Influence of Plasma Factors}

Although immunolocalization and signal intensity in control lungs perfused in the presence of $1.5 \%$ plasma were comparable with plasma-free control lungs, activation and regulation of $\mathrm{p}-\mathrm{p} 38$ in response to LPS were clearly influenced by the addition of soluble plasma factors (Table 4). Increase of p38 activation in $\mathrm{CD}^{-}$cell types (Ermert et al, 
Table 1. Quantification of p38 Staining Intensity: ${ }^{a}$ Experiments Performed in the Absence of Plasma

\begin{tabular}{|c|c|c|c|c|c|}
\hline Structures & Control & $\begin{array}{l}\text { 1,000 ng/ml LPS } \\
\text { 1-hr perfusion time }\end{array}$ & $\begin{array}{l}\text { 1,000 ng/ml LPS } \\
\text { 2-hr perfusion time }\end{array}$ & $\begin{array}{l}10,000 \mathrm{ng} / \mathrm{ml} \text { LPS } \\
\text { 1-hr perfusion time }\end{array}$ & $\begin{array}{l}10,000 \mathrm{ng} / \mathrm{ml} \text { LPS } \\
\text { 2-hr perfusion time }\end{array}$ \\
\hline $\begin{array}{l}\text { Bronchial epithelial cells of bronchi (1st } \\
\text { and 2nd generation) }\end{array}$ & $2150( \pm 104)$ & $2288( \pm 404)$ & $1386( \pm 196)^{\star \star \star} / \# \# \#$ & $2268( \pm 363)$ & $1709( \pm 235)$ \\
\hline $\begin{array}{l}\text { Bronchial epithelial cells of bronchi } \\
\text { (3rd generation) and bronchioli }\end{array}$ & $1719( \pm 259)$ & $2040( \pm 221)$ & $1174( \pm 123)^{\star *} / \# \# \#$ & $2310( \pm 155)^{\star *}$ & 1707 (土 99)\#\# \\
\hline BSMC & $1221( \pm 129)$ & $1655( \pm 230)^{*}$ & $1000( \pm 104) \# \# \#$ & $1405( \pm 150)$ & $1414( \pm 171)$ \\
\hline Cells of the BALT & $1261( \pm 94)$ & $1414( \pm 68)$ & $1144( \pm 103)$ & $1323( \pm 233)$ & $1247( \pm 79)$ \\
\hline Nerve fibers & $1296( \pm 150)$ & $1342( \pm 307)$ & $1550( \pm 180)$ & $1143( \pm 166)$ & $1094( \pm 63)$ \\
\hline Alveolar macrophages & $1614( \pm 179)$ & $2179( \pm 315)^{\star \star}$ & 1253 ( \pm 142$) \# \# \#$ & $2019( \pm 266)^{\star}$ & $1459( \pm 215) \# \#$ \\
\hline Peribronchial or perivascular leukocytes & $1366( \pm 254)$ & $1895( \pm 288)^{\star}$ & 1050 ( \pm 223$) \# \# \#$ & $1872( \pm 190)^{\star}$ & $1387( \pm 331) \#$ \\
\hline $\begin{array}{l}\text { Septal cells (predominantly type II } \\
\text { pneumocytes) }\end{array}$ & $2269( \pm 315)$ & $2266( \pm 187)$ & $1238( \pm 127)^{\star \star \star} / \# \# \#$ & $2039( \pm 278)$ & $1524( \pm 238)^{\star \star *} / \# \#$ \\
\hline Alveolar septum & ND & ND & ND & ND & ND \\
\hline Endothelial cells (not microvascular) & $1459( \pm 185)$ & $1961( \pm 143)^{\star \star}$ & $1387( \pm 241) \# \# \#$ & $1817( \pm 252)^{\star}$ & 1387 (土 178)\#\# \\
\hline VSMC of partially muscular vessels & $1168( \pm 124)$ & $1672( \pm 156)^{\star \star \star}$ & $999( \pm 97) \# \# \#$ & $1514( \pm 169)^{\star}$ & $1264( \pm 320)$ \\
\hline VSMC of fully muscular vessels & $1102( \pm 73)$ & $1544( \pm 70)^{\star \star}$ & $1058( \pm 148) \# \#$ & $1440( \pm 201)^{*}$ & $1383( \pm 222)$ \\
\hline VSMC of large arteries at the hilum & ND & ND & ND & ND & ND \\
\hline $\begin{array}{l}\text { Cardiac myocytes of large veins at the } \\
\text { hilum }\end{array}$ & $1008( \pm 189)$ & $1264( \pm 264)$ & $935( \pm 70)$ & $1240( \pm 209)$ & $1190( \pm 240)$ \\
\hline
\end{tabular}

\footnotetext{
${ }^{a}$ Mean gray values \pm SEM values for each group of buffer-perfused lungs are given. Each group comprised five independent lung experiments, and cross-sections from three randomly selected tissue blocks originating from different lung lobes were investigated per lung.

${ }^{*} p<0.05,{ }^{* *}<0.01,{ }^{* *}<0.001$ versus control; $\# p<0.05, \# \#<0.01, \# \#<0.001 ; 2 \mathrm{hr}$ versus $1 \mathrm{hr}$.

ND, staining not detected.
}

Table 2. Quantification of p38 Staining Intensity: ${ }^{a}$ Experiments Performed in the Presence of $1.5 \%$ Plasma

\begin{tabular}{|c|c|c|c|c|c|}
\hline Structures & Control & $\begin{array}{l}\text { 1,000 ng/ml LPS } \\
\text { 1-hr perfusion time }\end{array}$ & $\begin{array}{l}1,000 \mathrm{ng} / \mathrm{ml} \mathrm{LPS} \\
\text { 2-hr perfusion time }\end{array}$ & $\begin{array}{l}\text { 10,000 ng/ml LPS } \\
\text { 1-hr perfusion time }\end{array}$ & $\begin{array}{l}\text { 10,000 ng/ml LPS } \\
\text { 2-hr perfusion time }\end{array}$ \\
\hline $\begin{array}{l}\text { Bronchial epithelial cells of bronchi (1st and } \\
\text { 2nd generation) }\end{array}$ & $2232( \pm 157)$ & $2275( \pm 248)$ & $1709( \pm 127)^{\star} / \# \#$ & $2259( \pm 144)$ & $1668( \pm 201)^{\star} / \# \#$ \\
\hline $\begin{array}{l}\text { Bronchial epithelial cells of bronchi (3rd } \\
\text { generation) and bronchioli }\end{array}$ & $1971( \pm 258)$ & $2164( \pm 212)$ & $1474( \pm 342)^{\star} / \# \#$ & $2049( \pm 414)$ & $1546( \pm 274) \#$ \\
\hline BSMC & $1341( \pm 108)$ & $1670( \pm 202)$ & $1282( \pm 299)$ & $1588( \pm 192)$ & $1188( \pm 192)$ \\
\hline Cells of the BALT & $1189( \pm 35)$ & $1383( \pm 70)$ & $1163( \pm 124)$ & $1241( \pm 53)$ & $1114( \pm 163)$ \\
\hline Nerve fibers & $1253( \pm 189)$ & $1379( \pm 207)$ & $1260( \pm 460)$ & $1231( \pm 84)$ & $961( \pm 138)$ \\
\hline Alveolar macrophages & $1601( \pm 233)$ & $2205( \pm 148)^{\star \star * *}$ & $1612( \pm 130) \# \# \#$ & $2055( \pm 215)^{\star \star}$ & 1489 ( \pm 188$) \# \#$ \\
\hline Peribronchial or perivascular leukocytes & $1312( \pm 171)$ & $1767( \pm 167)^{\star}$ & $1375( \pm 190) \#$ & $1732( \pm 200)^{\star}$ & $1374( \pm 166) \#$ \\
\hline $\begin{array}{l}\text { Septal cells (predominantly type II } \\
\text { pneumocytes) }\end{array}$ & $2074( \pm 131)$ & $2011( \pm 186)$ & $1591( \pm 176)^{\star \star} / \# \#$ & $1732( \pm 161)$ & $1497( \pm 240)^{\star * \star}$ \\
\hline Alveolar septum & ND & ND & ND & ND & ND \\
\hline Endothelial cells (not microvascular) & $1567( \pm 230)$ & $1994( \pm 121)^{\star}$ & $1689( \pm 151)$ & $1896( \pm 232)^{\star}$ & $1330( \pm 98) \# \# \#$ \\
\hline VSMC of partially muscular vessels & $1224( \pm 107)$ & $1578( \pm 104)^{\star *}$ & $1213( \pm 122) \#$ & $1657( \pm 170)^{\star \star}$ & $1207( \pm 124) \# \#$ \\
\hline VSMC of fully muscular vessels & $1338( \pm 160)$ & $1674( \pm 251)$ & $1313( \pm 208)$ & $1595( \pm 180)$ & $1403( \pm 112)$ \\
\hline VSMC of large arteries at the hilum & ND & ND & ND & ND & ND \\
\hline Cardiac myocytes of large veins at the hilum & $1074( \pm 119)$ & $1376( \pm 226)$ & $1143( \pm 60)$ & $1231( \pm 154)$ & $936( \pm 71)$ \\
\hline
\end{tabular}

${ }^{a}$ See footnote to Table 1.

$2000 \mathrm{~b})$, such as bronchial epithelial cells of small bronchi (Fig. 6A) or endothelial cells (Fig. 6B), differed in buffer and buffer/plasma-perfused lungs. A prominent increase of $p$-p38 signal intensity was found in these cell types only when plasma had been added to the buffer perfusate. In contrast, CD $14^{+}$pulmonary cells types (Ermert et al, 2000b) showed increased p-p38 signal intensity both in the presence and absence of plasma factors (Tables 3 and 4, Fig. 6, C and D).

\section{Discussion}

MAPKs have been implicated in a variety of cellular functions including regulation of cell growth, cellular differentiation, and stress response (Ono and Han, 2000; Paul et al, 1997). In the current study, involvement of p38 in LPS-induced Cox-2/thromboxanedependent priming responses was investigated. Both physiologic and morphologic techniques were applied, and LPS priming of vascular and bronchial 
Table 3. Quantification of Phosphorylated p38 (p-p38) Staining Intensity: ${ }^{a}$ Experiments Performed in the Abscence of Plasma

\begin{tabular}{|c|c|c|c|c|c|}
\hline Structures & Control & $\begin{array}{l}1,000 \mathrm{ng} / \mathrm{ml} \mathrm{LPS} \\
1 \text {-hr perfusion time }\end{array}$ & $\begin{array}{l}\text { 1,000 } \mathrm{ng} / \mathrm{ml} \mathrm{LPS} \\
\text { 2-hr perfusion time }\end{array}$ & $\begin{array}{l}10,000 \mathrm{ng} / \mathrm{ml} \text { LPS } \\
\text { 1-hr perfusion time }\end{array}$ & $\begin{array}{l}10,000 \mathrm{ng} / \mathrm{ml} \text { LPS } \\
\text { 2-hr perfusion time }\end{array}$ \\
\hline $\begin{array}{l}\text { Bronchial epithelial cells of bronchi (1st } \\
\text { and 2nd generation) }\end{array}$ & $1692( \pm 64)$ & $1792( \pm 315)$ & $978( \pm 111)^{\star \star \star} / \# \# \#$ & $2130( \pm 246)^{\star}$ & $1174( \pm 178)^{\star *} / \# \# \#$ \\
\hline $\begin{array}{l}\text { Bronchial epithelial cells of bronchi (3rd } \\
\text { generation) and bronchioli }\end{array}$ & $1407( \pm 158)$ & $1228( \pm 138)$ & $910( \pm 78)^{\star \star}$ & $1542( \pm 359)$ & $949( \pm 83)^{\star \star} / \# \# \#$ \\
\hline BSMC & ND & $809( \pm 80)$ & $693( \pm 147)$ & $759( \pm 148)$ & $781( \pm 83)$ \\
\hline Cells of the BALT & ND & ND & ND & ND & ND \\
\hline Nerve fibers & $838( \pm 92)$ & $905( \pm 122)$ & $888( \pm 139)$ & $843( \pm 88)^{\star}$ & $928( \pm 61) \#$ \\
\hline Alveolar macrophages & $1193( \pm 114)$ & $1468( \pm 272)$ & $1064( \pm 131) \#$ & $1725( \pm 300)^{* * *}$ & 1173 ( \pm 119)\#\#\# \\
\hline Peribronchial or perivascular leukocytes & $946( \pm 54)$ & $1555( \pm 64)^{*}$ & $1404( \pm 430)^{\star}$ & $1595( \pm 342)^{\star}$ & $1495( \pm 224)^{*}$ \\
\hline $\begin{array}{l}\text { Septal cells (predominantly type II } \\
\text { pneumocytes) }\end{array}$ & ND & $1079( \pm 198)$ & $963( \pm 95)$ & $1496( \pm 324)$ & 1035 ( \pm 80)\#\# \\
\hline Alveolar septum & ND & ND & ND & ND & ND \\
\hline Endothelial cells (not microvascular) & $1168( \pm 171)$ & $1279( \pm 56)$ & $987( \pm 78)$ & $1459( \pm 134)^{\star}$ & 1026 ( \pm 72)\#\#\# \\
\hline VSMC of partially muscular vessels & $937( \pm 158)$ & $1100( \pm 62)^{*}$ & $743( \pm 62)^{\star} / \# \# \#$ & $1129( \pm 68)^{\star}$ & $829( \pm 52) \# \# \#$ \\
\hline VSMC of fully muscular vessels & ND & $945( \pm 145)$ & $720( \pm 76)$ & $881( \pm 202)$ & $796( \pm 102)$ \\
\hline VSMC of large arteries at the hilum & ND & ND & ND & ND & ND \\
\hline $\begin{array}{l}\text { Cardiac myocytes of large veins at the } \\
\text { hilum }\end{array}$ & ND & ND & ND & ND & ND \\
\hline
\end{tabular}

\footnotetext{
${ }^{a}$ Mean gray values \pm SEM for each group of buffer-perfused lungs are given. Each group comprised five independent lung experiments, and cross-sections from three randomly selected tissue blocks originating from different lung lobes were investigated per lung.

${ }^{*} p<0.05,{ }^{* *}<0.01,{ }^{* \star *}<0.001$ versus control; cell types without basal p38 activity are compared against groups receiving $1,000 \mathrm{ng} / \mathrm{ml}$ LPS for $1 \mathrm{hr}$; $p<$ $0.05, \#$, 0.01 , \#\#\# $<0.0012 \mathrm{hr}$ versus $1 \mathrm{hr}$.
}

Table 4. Quantification of Phosphorylated p38 (p-p38) Staining Intensity: ${ }^{a}$ Experiments Performed in the Presence of $1.5 \%$ Plasma

\begin{tabular}{|c|c|c|c|c|c|}
\hline Structures & Control & $\begin{array}{l}\text { 1,000 } \mathrm{ng} / \mathrm{ml} \text { LPS } \\
\text { 1-hr perfusion time }\end{array}$ & $\begin{array}{l}\text { 1,000 } \mathrm{ng} / \mathrm{ml} \mathrm{LPS} \\
\text { 2-hr perfusion time }\end{array}$ & $\begin{array}{l}10,000 \mathrm{ng} / \mathrm{ml} \text { LPS } \\
\text { 1-hr perfusion time }\end{array}$ & $\begin{array}{l}10,000 \mathrm{ng} / \mathrm{ml} \mathrm{LPS} \\
\text { 2-hr perfusion time }\end{array}$ \\
\hline $\begin{array}{l}\text { Bronchial epithelial cells of bronchi (1st } \\
\text { and } 2 \text { nd generation) }\end{array}$ & $1678( \pm 185)$ & $2214( \pm 188)^{\star *}$ & $1787( \pm 391)$ & $2403( \pm 120)^{\star \star \star}$ & $1241( \pm 164)^{\star} / \# \# \#$ \\
\hline $\begin{array}{l}\text { Bronchial epithelial cells of bronchi (3rd } \\
\text { generation) and bronchioli }\end{array}$ & $1276( \pm 51)$ & $1613( \pm 102)^{*}$ & $1371( \pm 257)$ & $1607( \pm 109)^{\star}$ & 996 ( \pm 115$) \# \# \#$ \\
\hline BSMC & ND & $900( \pm 187)$ & $752( \pm 131)$ & $1097( \pm 196)$ & $968( \pm 93)$ \\
\hline Cells of the BALT & ND & ND & ND & ND & ND $( \pm)$ \\
\hline Nerve fibers & $991( \pm 67)$ & $904( \pm 41)^{\star *}$ & $943( \pm 146) \# \#$ & $943( \pm 40)$ & $766( \pm 47)$ \\
\hline Alveolar macrophages & $1404( \pm 196)$ & $1809( \pm 151)^{*}$ & $1445( \pm 241) \#$ & $1837( \pm 183)^{\star}$ & 1124 ( \pm 109)\#\#\# \\
\hline Peribronchial or perivascular leukocytes & $973( \pm 114)$ & $1604( \pm 180)^{*}$ & $2025( \pm 284)^{\star \star \star}$ & $1721( \pm 245)^{\star *}$ & $1980( \pm 297)^{\star \star * *}$ \\
\hline $\begin{array}{l}\text { Septal cells (predominantly type II } \\
\text { pneumocytes) }\end{array}$ & ND & $1069( \pm 93)$ & $1160( \pm 187)$ & $1428( \pm 169)$ & 1067 ( \pm 73)\# \\
\hline Alveolar septum & ND & ND & ND & ND & ND \\
\hline Endothelial cells (not microvascular) & $1270( \pm 172)$ & $1545( \pm 192)^{*}$ & $1342( \pm 158)$ & $1920( \pm 209)^{\star \star *}$ & 1155 ( \pm 85$) \# \# \#$ \\
\hline VSMC of partially muscular vessels & $929( \pm 64)$ & $1101( \pm 89)^{\star}$ & 798 ( \pm 66$) \# \# \#$ & $1265( \pm 162)^{\star \star *}$ & $859( \pm 95) \# \# \#$ \\
\hline VSMC of fully muscular vessels & ND & $1025( \pm 151)$ & $964( \pm 123)$ & $1211( \pm 204)$ & $741( \pm 145) \# \# \#$ \\
\hline VSMC of large arteries at the hilum & ND & ND & ND & ND & $N D( \pm)$ \\
\hline $\begin{array}{l}\text { Cardiac myocytes of large veins at the } \\
\text { hilum }\end{array}$ & ND & ND & ND & ND & $N D( \pm)$ \\
\hline
\end{tabular}

a See footnote to Table 3.

responses to subsequent inflammatory challenge was evoked as previously described for isolated perfused rat lungs (Ermert et al, 2000b, 2000c).

Although MAPKs have been frequently studied under inflammatory conditions, scarce information about involvement in physiologic functions is available. The cellular expression of p38 and its activated form, $\mathrm{p}-\mathrm{p} 38$, was investigated by immunohistochemical techniques in control and endotoxin-challenged rat lung tissue. While almost all pulmonary cells types constitutively expressed the p38 MAPK, the activated form p-p38 was only detected in a few cell types under baseline conditions: in bronchial epithelial cells, endothelial cells, and VSMC of mainly small pulmonary vessels. Selective inhibition with p38 inhibitors resulted in dose-dependent reduction of $A A$-induced 

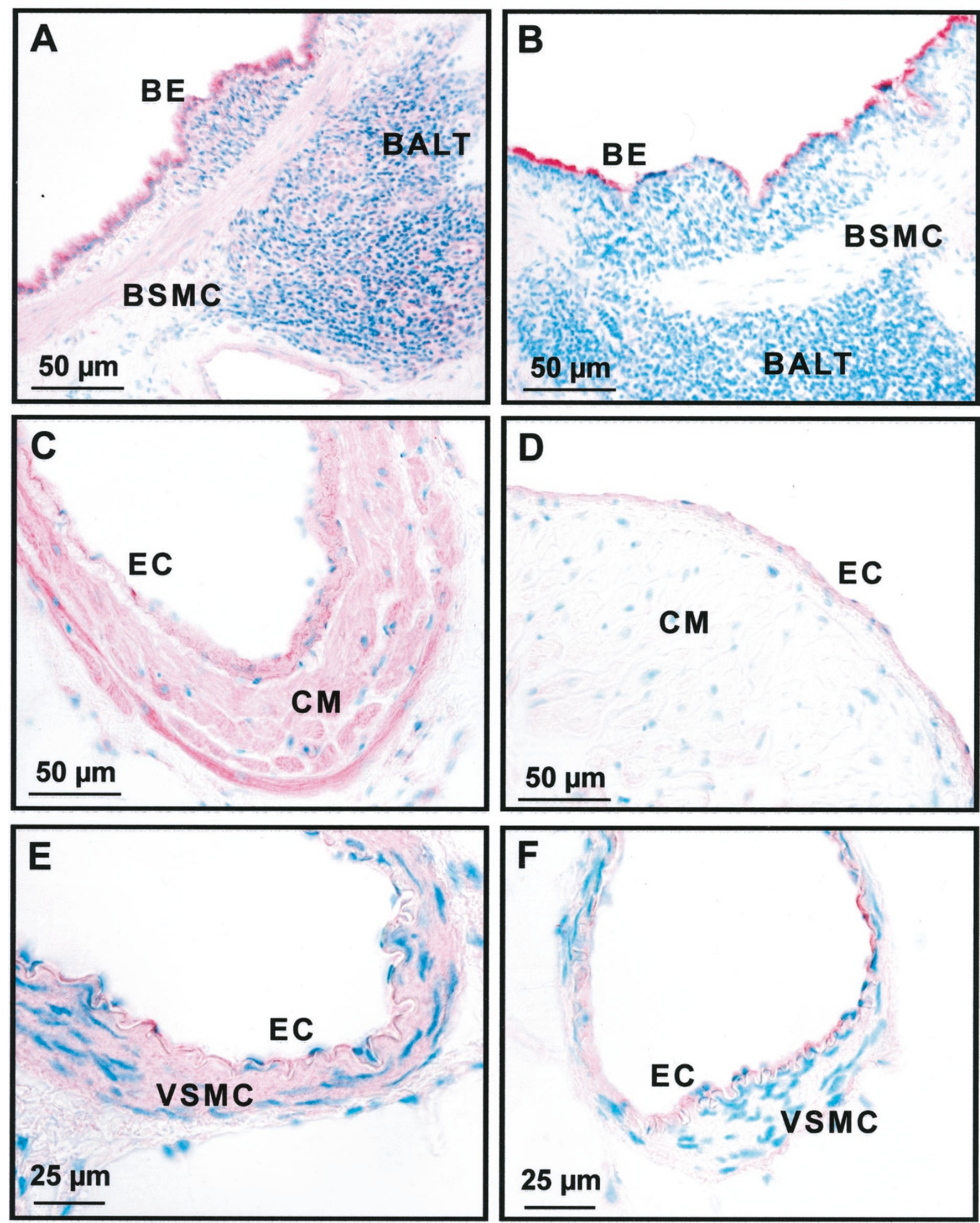

Figure 3.

Immunolocalization of p38 MAPK (left panels) and its activated/phosphorylated form p-p38 (right panels) in rat lung tissue. Positive immunostaining is shown as red alkaline phosphatase staining with methyl green nuclear counterstaining. A, p38 immunostaining was detected in bronchial epithelial cells ( $B E$ ), in bronchial smooth muscle cells (BSMC), and within the bronchus-associated lymphoid tissue $(B A L T)$. B, Activated p38, in contrast, was only localized to bronchial epithelial cells. $\mathrm{C}$ and $\mathrm{E}$, Constitutive $\mathrm{p38}$ expression was found in cardiac muscle cells (CM) of large hilum veins, vascular smooth muscle cells (VSMC) of intrapulmonary vessels, and endothelial cells $(E C)$. D and F, The activated form p-p38 was detected in endothelial cells of all pulmonary vessels.

PAP elevation and $\Delta \mathrm{W}$ in control lungs. In parallel, a marked reduction of $\mathrm{TxB}_{2}$, but not 6-keto $\mathrm{PGF}_{1 \alpha}$, into the recirculating buffer fluid was noted. This interfer- ence of p38 inhibition with thromboxane formation and pulmonary artery pressor response is in line with previous studies on Cox-2/thromboxane synthase im- 
munolocalization in control lungs (Ermert et al, 1998b, 2000a), which was predominantly localized in VSMC of partially muscular vessels. Partially muscular vessels represent pulmonary resistance vessels, which are mainly responsible for vascular tone regulation. Moreover, selective Cox-2 inhibitor studies have demonstrated that the AA-induced thromboxane formation underlying pressor response and edema formation in control rat lungs largely proceeds via the Cox-2thromboxane synthase axis (Ermert et al, 1998a). The present study extends this concept in showing that this physiologic prostanoid-mediated vasoregulatory loop is apparently p38 dependent. Interestingly, involvement of p38 MAPK in physiologic regulation has recently also been observed in Cox-2-dependent salt and water homeostasis in the kidney (Harris and Breyer, 2001).

In addition to vasculature endothelial cells and VSMC, pulmonary leukocytes such as alveolar macrophages and peribronchial and perivascular leukocytes displayed some p38 activity in nonstimulated lungs, which may reflect leukocytal immune defense. This is in line with observations showing the necessity of ERK and p38 MAPK for cytokine gene transcription (Carter et al, 1999; Nick et al, 1999), which may, even under control conditions, be important for the regulation of normal tissue homeostasis via paracrine mechanisms as was assumed (eg for TNF- $\alpha$ ) (Sherry and Cerami, 1988).

LPS priming has previously been shown to result in Cox-2/thromboxane-dependent strong enhancement of vascular and bronchial reactivity to inflammatory challenge, such as administration of free $A A$, which was a result of rapid up-regulation of both Cox-2 and thromboxane synthase in various cell types within the lung tissue (Ermert et al, 2000a, 2000b, 2000c). The current study strongly supports the notion that p38 MAPK is centrally involved in the LPS priming of the Cox-2/thromboxane synthase axis. Two independent p38 inhibitors both reduced AA-induced vascular and bronchial pressure elevation and $\Delta \mathrm{W}$ in LPS-primed lungs in a dose-dependent fashion. Previous reports have proven the specificity of the p38 inhibitors, which selectively inhibit both p38 homologs, p38 and p38 $\beta$ (Cuenda et al, 1995; Kumar et al, 1999; Lee et al, 2000).

In parallel, inhibition of thromboxane liberation into the buffer perfusate was observed, whereas in contrast, release of prostacyclin was not affected by p38 inhibition. These findings are thus fully in line with the recent observation of prostanoid-dependent pulmonary vasotone and bronchotone regulation via a Cox2/thromboxane synthase axis under both baseline and inflammatory conditions (Ermert et al, 1998a, 2000c). Moreover, the present findings support an involvement of the p38 MAPK in the LPS-induced signal transduction leading to up-regulation of the Cox-2/ thromboxane effector system. This view is in accordance with in vitro studies in macrophage cell lines, which already suggested a crucial role of p38 MAPK in the regulation of Cox-2 expression upon LPS challenge (Chen et al, 1999; Hwang et al, 1997).
Involvement of p38 MAPK in Cox-2-dependent cellular functions, such as pulmonary vascular tone regulation, suggests a direct influence of p38 on Cox-2 expression or activity. Notably, recent in vitro studies have indeed shown that p38 may maintain Cox-2 mRNA stability and that p38 inhibition may cause rapid destabilization of Cox-2 mRNA (Dean et al, 1999; Lasa et al, 2000; Ridley et al, 1998).

Immunohistochemical localization of p38 MAPK and its activated form-the phosphorylated p38allows identification of the cell type-specific activation status of the p38 MAPK. The increase in signal intensity was evaluated by a recently described method of in situ microdensitometric measurements in LPSchallenged lung tissue (Ermert et al, 2001). Newly induced p38 activity in response to LPS was detected in BSMC. This finding correlates well with the previous observation that Cox-2 and thromboxane synthase are up-regulated after stimulation of rat lungs with LPS, resulting in an enhanced LPS-induced bronchotone reactivity (Ermert et al, 2000a, 2000b, 2000c). Moreover, a recent study reported involvement of p38 in the signal transduction pathway of IL-1 $\beta$-enhanced Cox-2 expression in cultured airway SMC, which was also inhibited by selective p38 inhibition (Laporte et al, 2000).

In addition, LPS-induced, new p38 activity was detected in VSMC of fully muscular pulmonary vessels, and the signal intensity for $p$-p38 was found to be further enhanced in VSMC of partially muscular vessels in response to this challenge. In accordance with the suppression of the pulmonary artery pressor response after p38 inhibition in LPS-treated rat lungs, increased LPS-induced p38 activity in VSMC fits with the recently observed elevated Cox-2/thromboxane expression in pulmonary resistance vessels under inflammatory conditions (Ermert et al, 2000a, 2000b).

Single cells within the alveolar septum, which expressed the p38 MAPK but showed no phosphorylation activity under baseline conditions, were observed to express p-p38 after LPS stimulation. We assume that most of the cells are alveolar type II cells because of their cuboidal morphology and typical localization within the septal corners (Mason and Williams, 1991). Moreover, A549 cells, a type II alveolar cell line, have been shown to be activated via p38 in response to inflammatory or mechanical stimulation (Kristof et al, 2001; Quinn et al, 1999).

In response to LPS stimulation, p38 MAPK activity was found to be increased in bronchial epithelial cells, alveolar macrophages, and perivascular and peribronchial leukocytes, all of which already expressed p38 activity under baseline conditions. Although p38 activity was elevated 1 hour after LPS stimulation, the activity was already down-regulated below baseline levels in most cell types after 2 hours. Only in perivascularly and peribronchially located leukocytes p38 activity was further increased 2 hours after LPS application. Studies of cultured macrophages support the view of an LPS-induced dose- and time-dependent phosphorylation of p38 MAPK (Chen et al, 1999; Hwang et al, 1997). Moreover, in human neutrophils, 


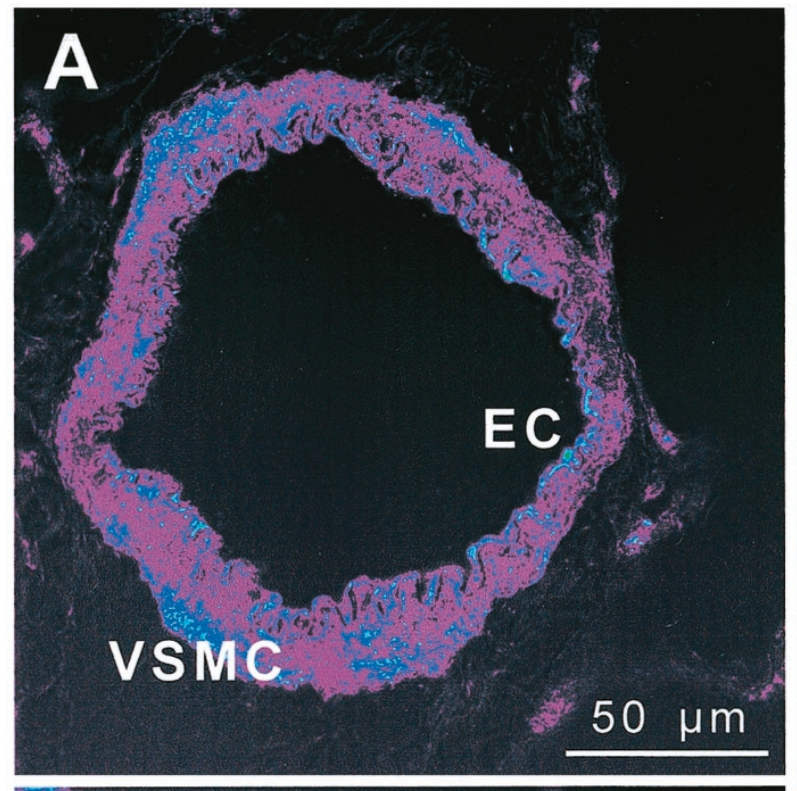

\section{B}
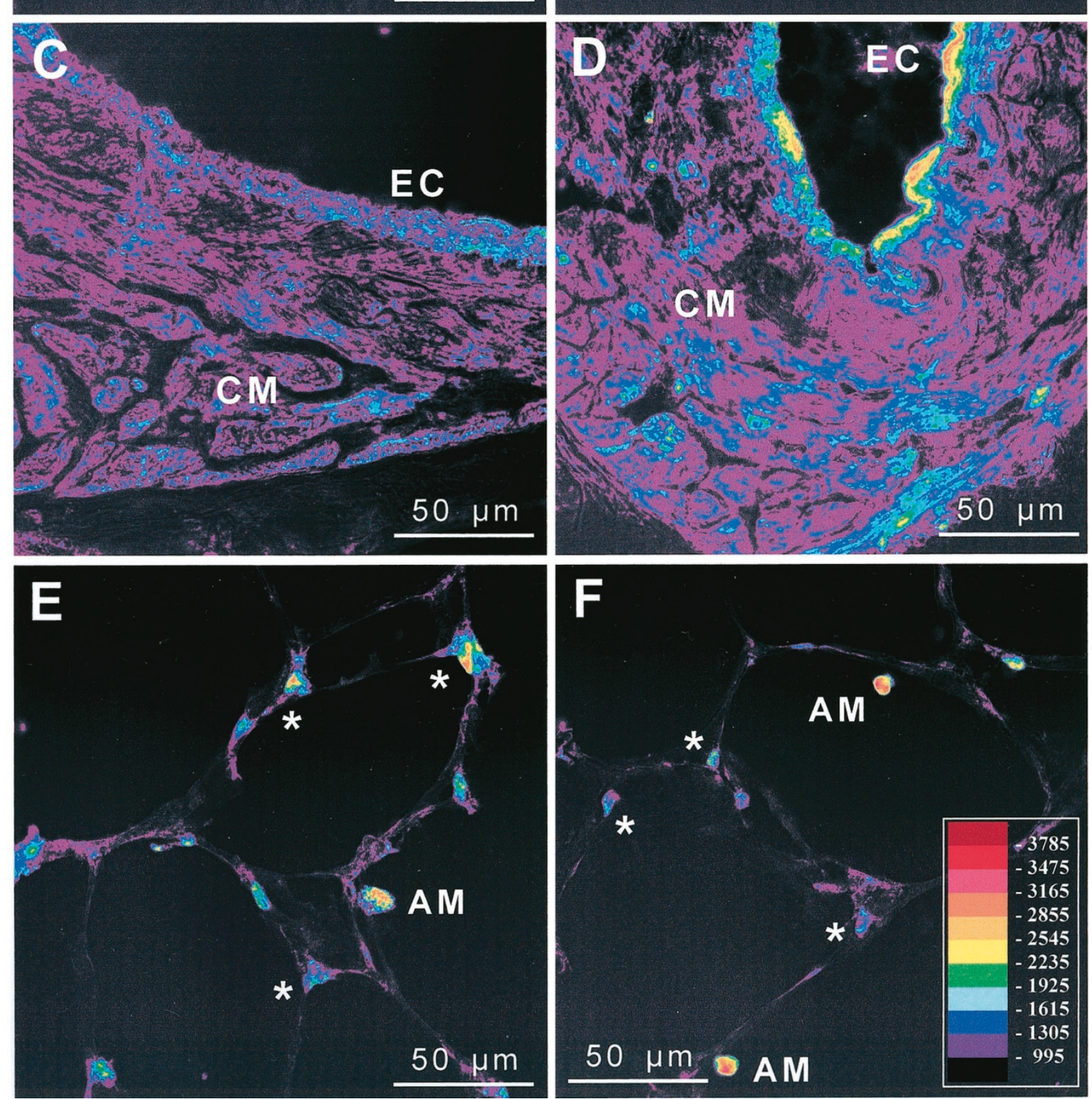
activation of p38 MAPK has been shown to occur in response to low-dose LPS stimulation $(100 \mathrm{ng} / \mathrm{ml})$ in vitro (Nahas et al, 1996). Activation of p38 and increase in the phosphorylated p38 were accompanied by short-term ( $\sim 1$ hour) increase of p38 signal intensity in most cell types followed by a decrease in signal intensity within 2 hours after LPS exposure. The decrease of p38 total immunoreactivity mostly occurred in parallel with the decrease of activated p38, which fell below baseline levels 2 hours after LPS administration.

The influence of soluble plasma factors such as LBP and soluble CD14 on the LPS-related activation of MAPK signal transduction in different target cells is of importance in view of the recently discovered TLRs as pathogen receptors (Chow et al, 1999; Rao, 2001). Among the TLR family, TLR-4 was found to be the major receptor responsible for intracellular transduction of LPS signaling and initiation of an inflammatory cascade (Kirschning and Bauer, 2001). CD14 acts as an important coreceptor within the LPS-receptor complex, and this is in line with the findings in the current study, in which an influence of soluble plasma factors on the activation of p38 MAPK was solely observed in distinct pulmonary cell types, being negative for CD14. Thus, in endothelial cells and bronchial epithelial cells of small bronchi (Ermert et al, 2000b), a major increase in p-p38 occurred only in the presence of soluble plasma factors. This is in accordance with previous studies in CD14-linked Cox-2 regulation: soluble plasma factor dependency on Cox-2 regulation was only detected in CD14 ${ }^{-}$cell types (Ermert et al, 2000b). Dependence of p38 activation on soluble plasma factors was previously also observed in in vitro studies in human neutrophils (Nahas et al, 1996; Nick et al, 1996, 1999), for which an enhanced stimulatory effect of LPS was reported upon combined use with serum.

Considering the involvement of p38 in LPS-induced signaling events with initiation of inflammatory cascades, which promote septic disease and may lead to multiorgan failure, this MAPK pathway is an interesting target protein for therapeutic intervention. Improvement of organ function and reduction of reperfusion injury have been noted in animal studies using selective p38 inhibitors in transplantation and inflammation experiments (Jarrar et al, 2000; Rakhit et al, 2001; Yoshinari et al, 2001). A possible therapeutic application of p38 inhibitors is discussed for several diseases, such as septic shock, arthritis, myocardial injury, or chronic obstructive pulmonary disease (Barnes, 2001; Lee et al, 1999, 2000; Liverton et al, 1999). The current study supports the view that inhibition of p38 MAPK inhibitors represents an interesting new therapeutic strategy to block LPS-induced alteration of vaso- and bronchoreactivity during septic lung disease. p38 inhibitors may be particularly effective in preventing the deleterious Cox-2-dependent priming responses in view of the fact that p38 may be involved in both stimulation of enhanced Cox-2 expression and maintenance of Cox-2 mRNA stability.

In conclusion, both microdensitometric analysis and pharmacologic studies strongly support the notion that the p38 MAPK pathway is involved in establishing an active Cox-2/thromboxane synthase axis in VSMC and $B S M C$ in rat lungs under both baseline and inflammatory conditions. Moreover, evidence is presented that phosphorylation of p38 is elicited by LPS in other lung cell types, including alveolar macrophages, perivascular leukocytes, and septal cells (type II pneumocytes), as well as endothelial and bronchial epithelial cells. The pathophysiologic consequences of an activation of these cells upon LPS contact remain to be elucidated.

\section{Materials and Methods}

\section{Reagents}

AA was obtained from Paesel and Lorei AG (Frankfurt, Germany). LPS (Salmonella abortus equi, s-form) was purchased from Cytogen (Bodenheim, Germany). ELISA kits for the determination of 6-keto $\mathrm{PGF}_{1 \alpha}$ and $\mathrm{TxB}_{2}$ were obtained from Cayman Chemical Company (Ann Arbor, Michigan) and R\&D Systems (Wiesbaden, Germany). The p38 inhibitors SB203580 and SC-68376 were purchased from Calbiochem-Novabiochem (Bad Soden, Germany). The Abs against p38 ( $\mathrm{H}-147)$ and phosphorylated p38 (D-8) were obtained from Santa Cruz (Heidelberg, Germany), and all secondary Abs were purchased from Biotrend (Cologne, Germany). Both Abs recognize the p38 homologs p38 and p38 $\beta$. The Vector Red Substrate Kit was acquired from Vector Laboratories (Burlingame, California). All other biochemicals were obtained from Merck (Darmstadt, Germany).

\section{Animals}

CD rats (Sprague-Dawley) were obtained from Charles River (Sulzfeld, Germany). All experimental procedures were performed in conformity with the guidelines of the United States National Institutes of Health (Guide for the Care and Use of Laboratory Animals, NIH Publication No. 86-23, revised 1985, United States Government Printing Office, Washington DC).

\section{Lung Isolation and Perfusion}

The rats (male, body weight 350-400 gm) were deeply anesthetized with sodium pentobarbital $(100 \mathrm{mg} / \mathrm{kg}$

\footnotetext{
Figure 4.

Image analysis with pseudocolor depiction of immunohistochemical p38 staining in control (left pane/s) and LPS-stimulated rat lung tissue (right pane/s). p38 staining intensity is increased in VSMC in response to LPS (B, 1,000 ng/ml LPS, 1 hour). Likewise, increased endothelial (EC) p38 expression is found after LPS challenge (D, $1,000 \mathrm{ng} / \mathrm{ml}$ LPS, 1 hour, 1.5\% plasma), whereas the expression of p38 in cardiac muscle cells (CM) remains unchanged. Within the lung parenchyma alveolar macrophages (AM) show marked up-regulation of p38 MAPK in response to LPS (F, 1,000 ng/ml LPS, 1 hour) in contrast to a decreased p38 expression in septal cells ( ${ }^{\star}$ predominantly type II pneumocytes).
} 


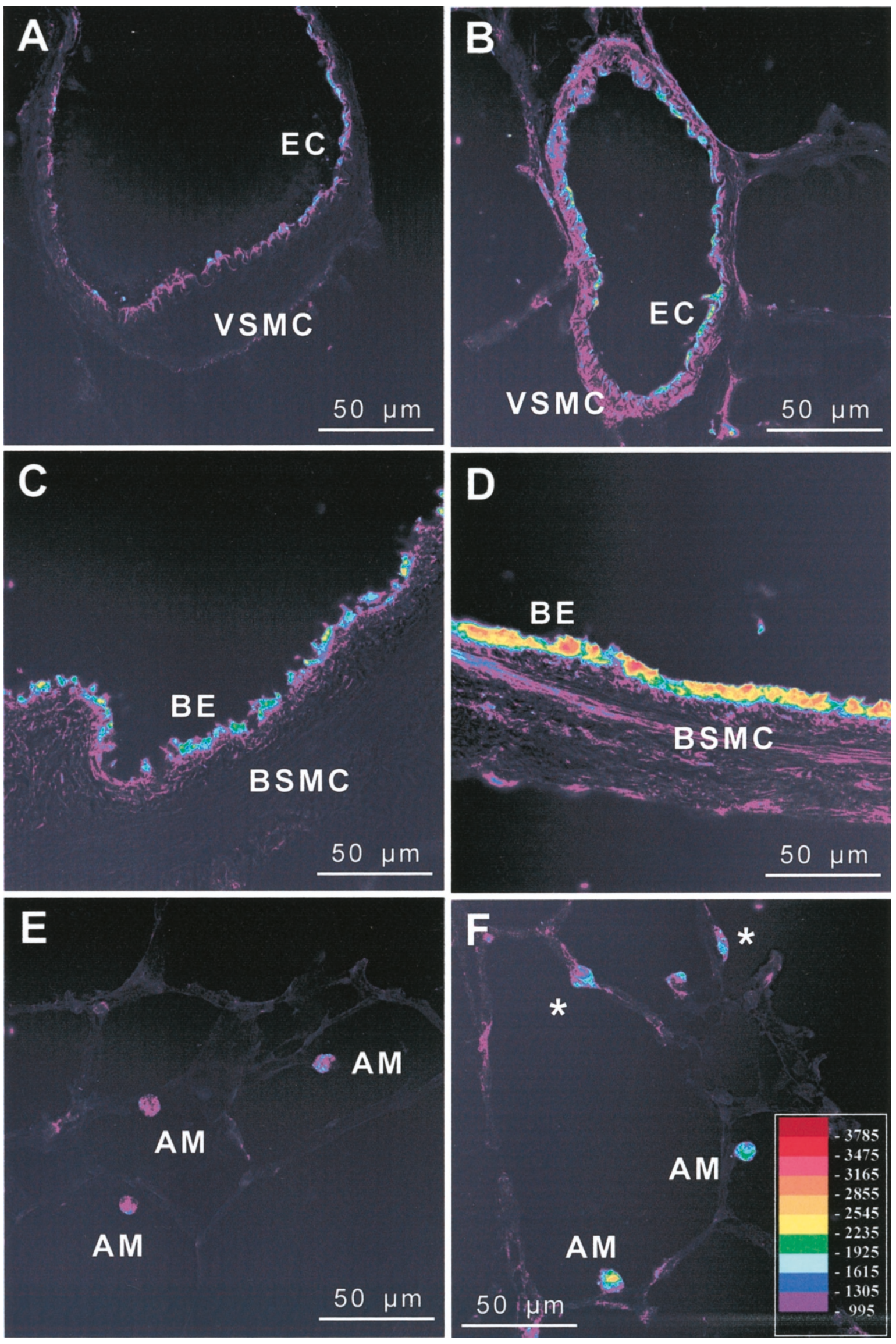


body weight ip). After local anesthesia with 2\% Xylocaine and median incision, the trachea was dissected and a tracheal cannula was immediately inserted. A median laparotomy was performed, and the rats were then anticoagulated with $1000 \mathrm{U}$ of heparin. Subsequently, mechanical ventilation was started with $4 \%$ $\mathrm{CO}_{2}, 17 \% \mathrm{O}_{2}$, and $79 \% \mathrm{~N}_{2}$ (tidal volume $4 \mathrm{ml}$, frequency $65 /$ minute, end expiratory pressure $3 \mathrm{~cm} \mathrm{H}_{2} \mathrm{O}$ ) using a small-animal respirator KTR-4 (Hugo Sachs Elektronik, Germany). After midsternal thoracotomy the right ventricle was incised, a cannula was fixed in the pulmonary artery, and the apex of the heart was cut off to allow pulmonary venous outflow. Simultaneously, pulsatile perfusion with buffer solution was started. The buffer contained $2.4 \mathrm{~mm} \mathrm{CaCl}_{2}, 1.3 \mathrm{~mm}$ $\mathrm{MgCl}_{2}, 4.3 \mathrm{~mm} \mathrm{KCl}, 1.1 \mathrm{~mm} \mathrm{KH_{2 }} \mathrm{PO}_{4}, 125.0 \mathrm{~mm} \mathrm{NaCl}$, $25 \mathrm{~mm} \mathrm{NaHCO}$ and $13.32 \mathrm{~mm}$ glucose $(\mathrm{pH}$ ranged between 7.35 and 7.40).

The lungs were carefully excised, avoiding any damage, while being perfused with buffer solution, and placed in an upright position. Next, a cannula was fixed through the left ventricle in the left atrium to obtain a closed perfusion circuit without leakage.

After extensive rinsing of the vascular bed, the lungs were perfused in a recirculating manner, with a pulsatile flow of $13 \mathrm{ml} /$ minute. The alternate use of two separate perfusion circuits, each containing $100 \mathrm{ml}$, allowed the repetitive exchange of perfusion fluid. Perfusion pressure (PAP), VP, and the weight of the isolated organ were registered continuously. The left atrial pressure was set at $2 \mathrm{mmHg}$ under baseline conditions ( 0 referenced at the hilum) to guarantee zone III conditions at end expiration throughout the lung.

Lungs selected for the study were those that (a) had a homogeneous white appearance without signs of hemostasis or edema formation, (b) had PAP and VP in the normal range, and (c) were isogravimetric during a steady-state period of 30 minutes.

\section{Experimental Protocol}

Pathomorphologic Experiments. In total, 55 isolated lung experiments were performed for histologic evaluation of p38 expression in rat lung tissue (Fig. 7). Five rat lungs were perfused for approximately 5 minutes for washout of blood. In control experiments, rat lungs were perfused for 2 hours solely with buffer fluid ( $n=$ 5). In additional experiments, LPS was admixed in concentrations of $1,000 \mathrm{ng} / \mathrm{ml}$ or $10,000 \mathrm{ng} / \mathrm{ml}$ to the recirculating buffer fluid. After administration of LPS, both 1-hour and 2-hour perfusion periods were used (each group $n=5$ ). All experiments were undertaken both in buffer-perfused lungs and in lungs with admixture of $1.5 \%$ rat plasma to the buffer fluid.

After termination of perfusion, the rat lungs were instilled with TissueTek OCT compound and frozen in liquid $\mathrm{N}_{2}$. The rat lungs were dissected into tissue blocks from all lobes and stored at $-80^{\circ} \mathrm{C}$. Sections (10- $\mu \mathrm{m}$ thickness) were cut from frozen tissue blocks of both left and right lungs.

Pathophysiologic Experiments. In total, 65 isolated lung experiments were performed with administration of p38 inhibitors, including control groups (Fig. 7). Control lungs were perfused in a recirculating manner under standard conditions for 125 minutes without any drug application $(n=5)$.

In experiments without LPS application $(n=5)$, free AA was admixed to the buffer perfusate at a concentration of $10 \mu \mathrm{mol} / \mathrm{L}$ after 2 hours of perfusion. LPS was admixed to the perfusate at the onset of the 2-hour perfusion period, resulting in concentrations of $10,000 \mathrm{ng} / \mathrm{ml}$ in the recirculating buffer fluid $(n=5)$. At the end of the 2-hour perfusion period, $10 \mu \mathrm{mol} / \mathrm{L} \mathrm{AA}$ was administered similarly to the lungs perfused in the absence of LPS.

The following concentrations of inhibitors were used to inhibit selectively p38 activity (Figs. 1 and 7): lungs were perfused either with or without application of 10,000 ng/ml LPS; after 60 minutes of perfusion, a p38 inhibitor (SB203580 or SC-68376) was administered at a final concentration of 1 to $40 \mu \mathrm{mol} / \mathrm{L}(n=5$ for each combination and inhibitor dosage).

In selected experiments, samples for perfusate analysis were taken at the onset of the 2-hour perfusion period ( 0 minutes), after 1 hour of perfusion (60 minutes), after 2 hours of perfusion before application of AA (120 minutes), and 2 and 5 minutes after AA admixture (122 minutes, 125 minutes) (see time schedule, Fig. 7).

\section{Perfusate Analysis}

$\mathrm{TxA}_{2}$ and $\mathrm{PGl}_{2}$ were assayed by ELISA from the recirculating buffer fluid as their stable hydrolysis products $\mathrm{TxB}_{2}$ and 6-keto $\mathrm{PGF}_{1 \alpha}$.

\section{Immunohistochemistry}

The sections were fixed for 5 minutes with 3\% paraformaldehyde solution and washed in PBS (PBS: 0.01 M, $150 \mathrm{~mm} \mathrm{NaCl}, \mathrm{pH} 7.6)$ for $3 \times 5$ minutes. They were treated for 15 minutes with a $1 \%$ Triton solution. The sections were preincubated in PBS containing 5\% goat serum, $1 \%$ BSA, and $0.05 \%$ Tween-20 to block nonspecific binding. Overnight incubation with the polyclonal primary Ab p38 $(\mathrm{H}-147)$ diluted $1 / 100$ in

\footnotetext{
Figure 5.

Image analysis with pseudocolor depiction of immunohistochemical p-p38 staining in control (left panels) and LPS-stimulated rat lung tissue (right panels). Phosphorylated p38 (p-p38) staining is newly detected in VSMC of fully muscular vessels in response to LPS, whereas the expression of $p$-p38 in endothelial cells $(E C)$ is increased after LPS stimulation (B, 10,000 ng/ml LPS, 1 hour, $1.5 \%$ plasma). Likewise, enhanced staining intensity for $p$-p38 is noted in bronchial epithelial cells $(B E)$ after LPS challenge (D, 10,000 ng/ml LPS, 1 hour). Note that BSMC are not stained in control $(C)$ lungs but show p38 activity after stimulation with LPS Staining intensity of alveolar macrophages $(A M)$ is markedly increased in LPS-treated lungs ( $F, 10,000 \mathrm{ng} / \mathrm{ml}$ LPS, 1 hour). New p-38 activity is detected in septal cells ( ${ }^{*}$ predominantly type II pneumocytes).
} 


\section{Quantitative evaluation of immunohistochemical staining intensity Activated form of p38 MAPK (p-p38)

A

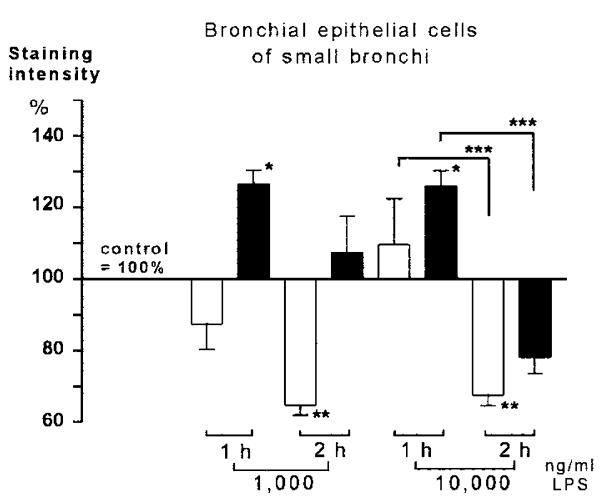

C

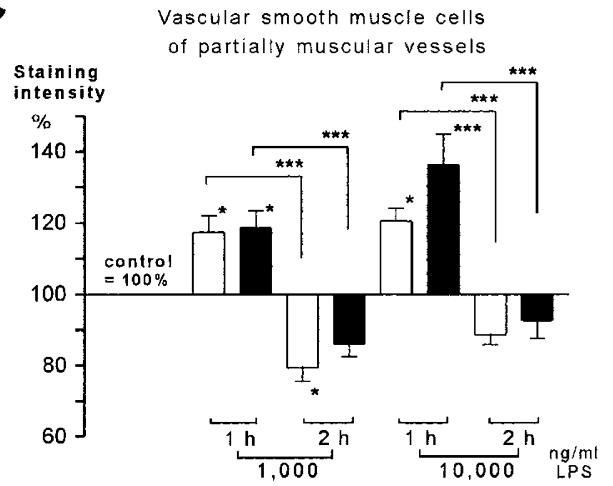

B

Endothelial cells of large vessels

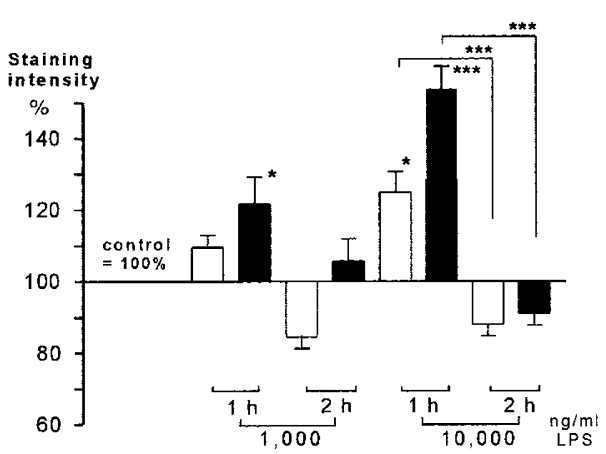

D

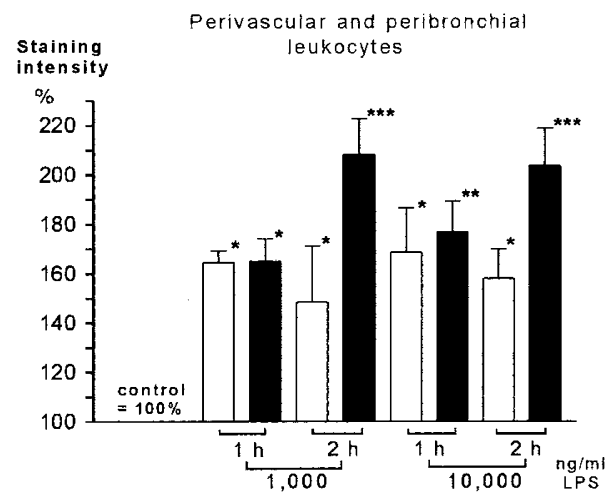

Figure 6.

Quantitative evaluation of phosphorylated p38 (p-p38) expression in response to LPS. Staining intensity is depicted in percent of gray scale values measured, with control lungs being set at 100\%. LPS challenge was performed in the absence (open bars) and in the presence (closed bars) of $1.5 \%$ plasma in the buffer perfusate. A time- and dose-dependent up-regulation of p38 activity 1 hour after LPS stimulation, followed by a decrease of expression after 2 hours, was noted in most cell types (A to C). However, differential dependency on plasma components was noted. In contrast increased expression of $p$-38 activity throughout the 2 hours after LPS application was found in perivascular or peribronchial leukocytes (D). Mean \pm SEM of five independent experiments each are given. ${ }^{\star} p<0.05,{ }^{* *} p<0.01,{ }^{* \star *} p$ $<0.001$, as compared with control lung cells. $\Pi^{\star} p<0.05, \Pi^{\star \star} p<0.01(+), \Pi^{\star \star \star} p<0.001(+)$ for 1- and 2-hour comparison.

PBS containing 1\% BSA, 0.05\% Tween-20, was performed at $4^{\circ} \mathrm{C}$. The antiphosphorylated p38 mAb (D-8) was used accordingly, at a dilution of $1 / 50$. The sections were then washed in PBS and incubated with a secondary $\mathrm{Ab}$ conjugated with alkaline phosphatase in the same dilution buffer overnight at $4^{\circ} \mathrm{C}$. Afterward, the sections were washed in PBS for $3 \times 5$ minutes. Subsequently, the sections were developed with a Vector Red Substrate Kit. Levamisole $2.5 \mathrm{~mm}$ was added to inhibit endogenous alkaline phosphatase activity. Counterstaining of the sections was performed with methyl green. Control staining was performed by omission of the primary Ab and substitution with nonspecific serum at the same dilution.

\section{Image Analysis}

The method has been described previously (Ermert et al, 2000a, 2001, 2002). Briefly, an image analysis system consisting of a 12-bit cooled CCD camera (Sensys KAF 1400; Photometrics, Tucson, Arizona) mounted on a fully automated Leica DM RXA (Leica, Wetzlar, Germany) was used to digitize gray scale images to a Dual-Pentium $200 \mathrm{MHz}$ host computer. Microscope settings were kept constant throughout all measurements (Objective: $\times 40$ oil, Leica PL Fluotar $40 \times / 0.75)$. A stabilized $12-\mathrm{V}$ tungsten-halogen lamp $(100 \mathrm{~W})$ was used for illumination. Microdensitometry was performed with a custom-designed filter for absorbance measurement of the substrate Vector Red (central wave length, $525 \mathrm{~nm}$; half band width, $10 \mathrm{~nm}$ $\pm 2 \mathrm{~nm}$ ) manufactured by Omega Optical Inc. (Brattleboro, Vermont).

Adjustment of all microscope settings was stored and recalled before measurement. Calibration of the measurement system with a reference slide was done before measurement. Gray scale images were digitized to 12 bit accuracy, resulting in an intensity scale ranging from 0 to 4095. Image analysis was performed by means of the image analysis program ImagePro 3.0 (Mediacybernetics). For direct visualization of staining intensity, a pseudocolor scale with 11 colors was chosen, each representing an equal sector of the intensity scale, and applied to the images. Background measurement was performed to evaluate the 


\section{Experimental protocol}

Pathomorphological experiments

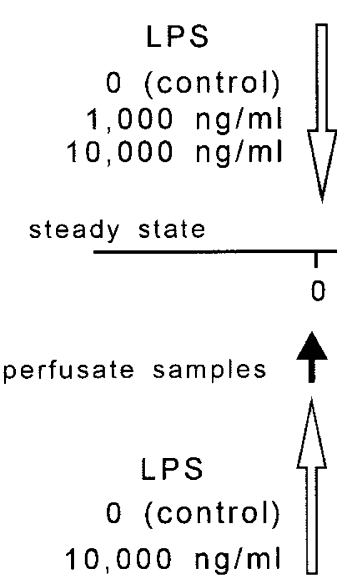

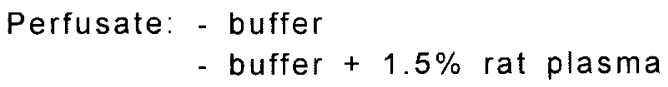

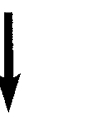

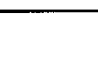

p38 Inhibitor

SB203580 $(0,1,5,10,20 \mu \mathrm{mol} / \mathrm{l})$

SC-68376 $(0,20,40 \mu \mathrm{mol} / \mathrm{l})$

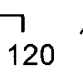

122125

个 $\mathbf{1}$

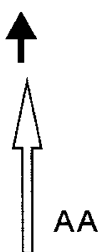

AA $10 \mu \mathrm{mol} / \mathrm{l}$

\section{Figure 7.}

Time schedule of pathomorphologic and pathophysiologic experiments with LPS administration, AA challenge, and inhibitor administration. Samples for perfusate analysis were always drawn before administration of the respective agents. For histologic tissue processing, experiments were terminated either 1 or 2 hours afterLPS administration. For details, see text.

influence of nonspecific staining and/or absorption of unstained tissue.

From each section, five images per stained structure were digitized and the area of interest was manually defined. The mean gray values were automatically measured and subsequently transferred into the spreadsheet program EXCEL (Microsoft Corporation, Redmond, Washington). Anatomic segments of the vascular tree were defined as recently described (Ermert et al, 2000a). In brief, elastic arteries as well as muscular and partially muscular vessels were distinguished by the structure of the vessel wall. Large arteries at the lung hilum were defined by the thickness of their muscle layer and the occurrence of elastic fibers, whereas hilum veins were identified by the cardiac muscle cells, which accompany the pulmonary veins of rats into the lung parenchyma.

\section{Statistical Analysis}

ANOVA was used to evaluate differences among different groups. A $p$ value $<0.05$ was considered significant. All data are given as mean \pm SEM.

\section{Acknowledgements}

The authors thank Mr. G. Müller for excellent technical assistance. The authors are grateful to Dr. R. L. Snipes, Department of Anatomy, University of Giessen for linguistic review of the manuscript.

\section{References}

Barnes PJ (2001). Future advances in COPD therapy. Respiration 68:441-448.

Brigham KL and Meyrick B (1986). Endotoxin and lung injury. Am Rev Respir Dis 133:913-927.

Carter AB, Monick MM, and Hunninghake GW (1999). Both Erk and p38 kinases are necessary for cytokine gene transcription. Am J Respir Cell Mol Biol 20:751-758.

Chen BC, Chen YH, and Lin WW (1999). Involvement of p38 mitogen-activated protein kinase in lipopolysaccharideinduced iNOS and Cox-2 expression in $\mathrm{J} 774$ macrophages. Immunology 97:124-129.

Chow JC, Young DW, Golenbock DT, Christ WJ, and Gusovsky $F$ (1999). Toll-like receptor-4 mediates lipopolysaccharide-induced signal transduction. J Biol Chem 274(16):10689-10692.

Cuenda A, Cohen P, Buée-Scherrer V, and Goedert M (1997). Activation of stress-activated protein kinase-3 (SAPK3) by cytokines and cellular stresses is mediated via SAPKK3 (MKK6): Comparison of the specificities of SAPK3 and SAPK2 (RK/p38). EMBO J 16(2):295-305.

Cuenda A, Rouse J, Doza YN, Meier R, Cohen P, Gallagher TF, Young PR, and Lee JC (1995). SB 203580 is a specific inhibitor of a MAP kinase homologue which is stimulated by cellular stresses and interleukin-1. FEBS Lett 364:229-233.

Dean JLE, Brook M, Clark AR, and Saklatvala J (1999). p38 mitogen-activated protein kinase regulates cyclooxygenase-2 mRNA stability and transcription in lipopolysaccharide-treated human monocytes. J Biol Chem 274(1):264-269. 
Ermert L, Ermert M, Althoff A, Merkle M, Grimminger F, and Seeger W (1998a). Vasculatory prostanoid generation proceeds via cyclooxygenase-2 in non-inflamed rat lungs. J Pharmacol Exp Ther 286:1309-1314.

Ermert L, Ermert M, Duncker HR, Grimminger F, and Seeger W (2000a). In-situ localization and regulation of thromboxane A2 synthase in normal and LPS-primed lungs. Am J Physiol Cell Mol Physiol 278:L744-L753.

Ermert L, Ermert M, Goppelt-Struebe M, Walmrath D, Grimminger F, Steudel W, Ghofrani HA, Homberger C, Duncker $\mathrm{HR}$, and Seeger W (1998b). Cyclooxygenase isoenzyme localization and mRNA expression in rat lungs. Am J Respir Cell Mol Biol 18:479-488.

Ermert L, Ermert M, Merkle M, Goppelt-Struebe M, Duncker HR, Grimminger F, and Seeger W (2000b). Rat pulmonary cyclooxygenase-2 expression in response to endotoxin challenge: Differential regulation in the various types of cells in the lung. Am J Pathol 156(4):1275-1287.

Ermert L, Hocke ACH, Duncker HR, Seeger W, and Ermert M (2001). Comparison of different detection methods in quantitative microdensitometry. Am J Pathol 158:407-417.

Ermert M, Merkle M, Mootz R, Grimminger F, Seeger W, and Ermert $L$ (2000c). Endotoxin priming of the cyclooxygenase2-thromboxane axis in isolated rat lungs. Am J Physiol Lung Cell Mol Physiol 278:L1195-L1203.

Ermert M, Ruppert C, Guenther A, Duncker HR, Seeger W, and Ermert L (2002). Cell-specific nitric oxide synthaseisoenzyme expression and regulation in response to endotoxin in intact rat lungs. Lab Invest 82:425-441.

Feng GJ, Goodridge HS, Harnett MM, Wei XQ, Nikolaev AV, Higson AP, and Liew FY (1999). Extracellular signal-related kinase $(E R K)$ and p38 mitogen-activated protein (MAP) kinases differentially regulate the lipopolysaccharide-mediated induction of inducible nitric oxide synthase and IL-12 in macrophages: Leishmania phosphoglycans subvert macrophage IL-12 production by targeting ERK MAP kinase. J Immunol 163:6403-6412.

Guan Z, Buckman SY, Pentland AP, Templeton DJ, and Morrison AR (1998). Induction of cyclooxygenase-2 by the activated MEKK1 $\rightarrow$ SEK2/MKK4 $\rightarrow$ p38 mitogen-activated protein kinase pathway. J Biol Chem 273(21):12901-12908.

Harris RC and Breyer MD (2001). Physiological regulation of cyclooxygenase-2 in the kidney. Am J Physiol Renal Physiol 281:F1-F11.

Haziot A, Ferrero E, Kontgen F, Hijiya N, Yamamoto S, Silver J, Stewart CL, and Goyert SM (1996). Resistance to endotoxin shock and reduced dissemination of gram-negative bacteria in CD14-deficient mice. Immunity 4:407-414.

Hoshino K, Takeuchi O, Kawai T, Sanjo H, Ogawa T, Takeda Y, Takea K, and Akira S (1999). Cutting edge: Toll-like receptor 4 (TLR4)-deficient mice are hyporesponsive to lipopolysaccharide: Evidence for TLR4 as the Lps gene product. J Immunol 162:3749-3752.

Hwang D, Jang BC, Yu G, and Boudreau M (1997). Expression of mitogen-inducible cyclooxygenase induced by lipopolysaccharide: Mediation through both mitogenactivated protein kinase and NF- $\kappa \mathrm{B}$ signaling pathways in macrophages. Biochem Pharmacol 54:87-96.

Ingalls RR and Golenbock DT (1995). CD11c/CD18, a transmembrane signaling receptor for lipopolysaccharide. J Exp Med 181:1473-1479.
Jarrar D, Wang P, Song GY, Cioffi WG, Bland KI, and Chaudry IH (2000). Inhibition of tyrosine kinase signaling after trauma-hemorrhage: A novel approach for improving organ function and decreasing susceptibility to subsequent sepsis. Ann Surg 231(3):399-407.

Kirschning CJ and Bauer S (2001). Toll-like receptors: Cellular signal transducers for exogenous molecular patterns causing immune responses. Int J Med Microbiol 291(4):251260.

Kristof AS, Marks-Konczalik J, and Moss J (2001). Mitogenactivated protein kinases mediate activator protein-1dependent human inducible nitric-oxide synthase promoter activation. J Biol Chem 276(11):8445-8452.

Kumar S, Jiang MS, Adams JL, and Lee JC (1999). Pyridinylimidazole compound SB 203580 inhibits the activity but not the activation of p38 mitogen-activated protein kinase. Biochem Biophys Res Commun 263:825-831.

Laporte JD, Moore PE, Lahiri T, Schwartzman IN, Panettieri RA Jr, and Shore SA (2000). p38 MAP kinase regulates IL-1b responses in cultured airway smooth muscle cells. Am $J$ Physiol Lung Cell Mol Physiol 279:L932-L941.

Lasa M, Mahtani KR, Finch A, Brewer G, Saklatvala J, and Clark A (2000). Regulation of cyclooxygenase 2 mRNA stability by the mitogen-activated protein kinase p38 signaling cascade. Mol Cell Biol 20(12):4265-4274.

Lee JC, Kassis S, Kumar S, Badger A, and Adams JL (1999). p38 mitogen-activated protein kinase inhibitors: Mechanisms and therapeutic potentials. Pharmacol Ther 82(2-3):389397.

Lee JC, Kumar S, Griswold DE, Underwood DC, Votta BJ, and Adams JL (2000). Inhibition of p38 MAP kinase as a therapeutic strategy. Immunopharmacology 47:185-201.

Liverton NJ, Butcher JW, Claiborne CF, Claremon DA, Libby BE, Nguyen KT, Pitzenberger SM, Selnick HG, Smith GR, Tebben A, Vacca JP, Varga SL, Agarwal L, Dancheck K, Forsyth AJ, Fletcher DS, Frantz B, Hanlon WA, Harper CF, Hofsess SJ, Kostura M, Lin J, Luell S, O'Neill EA, Orevillo CJ, Pang M, Parsons J, Rolando A, Sahly Y, Visco DM, and O'Keefe SJ (1999). Design and synthesis of potent, selective and orally bioavailable tetrasubstituted imidazole inhibitors of p38 mitogen-activated protein kinase. J Med Chem 42(12): 2180-2190.

Mason RJ and Williams MC (1991). Alveolar type II cells. In: Crystal RG and West JB, editors. The lung. New York: Raven Press, 235-246.

McLeish KR, Knall C, Ward RA, Gerwins P, Coxon PY, Klein JB, and Johnson GL (1998). Activation of mitogen-activated protein kinase cascades during priming of human neutrophils by TNF- $\alpha$ and GM-CSF. J Leukoc Biol 64:537-545.

Nahas N, Molski TFP, Fernandez GA, and Shaáfi RI (1996). Tyrosine phosphorylation and activation of a new mitogenactivated protein (MAP)-kinase cascade in human neutrophils stimulated with various agonists. Biochem J 318:247253.

Newton R, Cambridge L, Stevens DA, Linday MA, and Barnes PJ (2000). The MAP kinase inhibitors PD098059, U0126 and SB203580, inhibit IL-1beta-dependent PGE(2) release via mechanistically distinct processes. Br J Pharmacol 130:1353-1361.

Nick JA, Avdi NJ, Gerwins P, Johnson GL, and Worthen GS (1996). Activation of a p38 mitogen activated protein kinase 
in human neutrophils by lipopolysaccharide. J Immunol 156(12):4867-4875.

Nick JA, Avdi NJ, Young SK, Lehman LA, McDonald PP, Frasch SC, Billstrom MA, Henson PM, Johnson GL, and Worthen GS (1999). Selective activation and functional significance of $\mathrm{p} 38 \alpha$ mitogen-activated protein kinase in lipopolysaccharide-stimulated neutrophils. J Clin Invest 103: 851-858.

O’Neill L (2001). Specificity in the innate response: Pathogen recognition by Toll-like receptor combinations. Trends Immunol 22(2):70.

Ono $\mathrm{K}$ and Han $\mathrm{J}$ (2000). The p38 signal transduction pathway: Activation and function. Cell Signal 12:1-13.

Paul A, Wilson S, Belham CM, Robinson CJM, Scott PH, Gould GW, and Plevin R (1997). Stress-activated protein kinases: Activation, regulation and function. Cell Signal 9(6): 403-410.

Pugin J, Schürer-Maly CC, Leturcq D, Moriatry A, Ulevitch RJ, and Tobias PS (1993). Lipopolysaccharide activation of human endothelial and epithelial cells is mediated by lipopolysaccharide-binding protein and soluble CD14. Proc Natl Acad Sci USA 90:2744-2748.

Quinn D, Tager A, Joseph PM, Bonventre JV, Force T, and Hales CA (1999). Stretch-induced mitogen-activated protein kinase activation and interleukin-8 production in type II alveolar cells. Chest 116:89S-90S.

Qureshi S, Larivière L, Leveque G, Clermont S, Moore KJ, Gros P, and Malo D (1999). Endotoxin-tolerant mice have mutations in Toll-like receptor 4 (TIr4). J Exp Med 189(4):615625.

Raingeaud J, Gupta S, Rogers JS, Dickens M, Han J, Ulevitch RJ, and Davis RJ (1995). Pro-inflammatory cytokines and environmental stress cause p38 mitogen-activated protein kinase activation by dual phosphorylation on tyrosine and threonine. J Biol Chem 270(13):7420-7426.

Rakhit RD, Kabir AN, Mockridge JW, Saurin A, and Marber MS (2001). Role of G proteins and modulation of p38 MAPK activation in the protection by nitric oxide against ischemiareoxygenation injury. Biochem Biophys Res Commun 286(5): 995-1002.
Rao KM (2001). MAP kinase activation in macrophages. J Leukoc Biol 69(1):3-10.

Ridley SH, Dean JLE, Sarsfield SJ, Brook M, Clark AR, and Saklatvala J (1998). A p38 MAP kinase inhibitor regulates stability of interleukin-1-induced cyclooxygenase-2 mRNA. FEBS Lett 439:75-80.

Schwandner R, Dziarski R, Wesche H, Rothe M, and Kirsching CJ (1999). Peptidoglycan- and lipoteichoic acid-induced cell activation is mediated by Toll-like receptor 2 . J Biol Chem 274(25):17406-17409.

Sherry B and Cerami A (1988). Cachectin/tumor necrosis factor exerts endocrine, paracrine and autocrine control of inflammatory responses. J Cell Biol 107:1269-1277.

Ulevitch RJ (1991). Recognition of bacterial endotoxin in biologic systems. Lab Invest 65:121-122.

Wright SD, Ramos RA, Tobias PS, Ulevitch RJ, and Mathison JC (1990). CD14, a receptor for complexes of lipopolysaccharide (LPS) and LPS binding protein. Science 249:14311433.

Yang H, Young DW, Gusovsky F, and Chow JC (2000). Cellular events mediated by lipopolysaccharide-stimulated Toll-like receptor 4: MD-2 is required for activation of mitogen-activated protein kinases and Elk-1. J Biol Chem 275(27):20861-20866.

Yoshimura A, Lien E, Ingalls RR, Toumanen E, Dziarski R, and Golenbock D (1999). Recognition of gram-positive bacterial cell wall components by the innate immune system occurs via toll-like receptor 2. J Immunol 163:1-5.

Yoshinari D, Takeyoshi I, Kobayashi M, Koyama T, lijima K, Ohwada S, Matsumoto K, and Morishita Y (2001). Effects of a p38 mitogen-activated protein kinase inhibitor as an additive to University of Wisconsin solution on reperfusion injury in liver transplantation. Transplantation 72(1):22-27. 